\title{
ANALISIS KEPUASAN NASABAH ATAS PEMBIAYAAN BNI FLEKSI SYARIAH PADA PT. BANK BNI SYARIAH TANJUNGKARANG
}

\author{
Suwandi1 ${ }^{1}$ Soewito² \\ ${ }^{1}$ Institut Informatika dan Bisnis Darmajaya \\ 2Universitas Bandar Lampung \\ Email: suwandi@darmajaya.ac.id \\ soewito@ubl.ac.id
}

\begin{abstract}
PT. BNI of Fleksi Syariah Tanjungkarang represent financial institution with Moslem law principle which born as one of the alternative financial institution form to fulfill certain society segmentation which is viewer that bank flower represent collision to syariat Islam. The main objective of this research to know level satisfaction of client defrayal BNI Fleksi Syariah at PT. BNI of Fleksi Syariah Tanjungkarang.

Factors which influencing satisfaction of client PT. BNI of Fleksi Syariah which its handling require to be given high priority by company because existence of assessed this factor of vital importance by client, but management not yet executed him according to desire of customer

Factors or variable influencing satisfaction of client of PT. BNI Fleksi Syariah which need to be defended, because in general mount its execution have as according to client expectation and importance, so that can gratify client. Factors or variable influencing satisfaction of client of PT. BNI of Fleksi Syariah still assumed by less important its influence to customer, its executor by run of the mill company. Implication in improving service system at PT. Bank of BNI Fleksi Syariah Tanjungkarang shall perform a training and education to entire/all its employees especially to increase ability of employees in the case of: Comments handle sigh of customer and ability comprehend desire of customer.
\end{abstract}

Keyword: Satisfaction, Fleksi Syariah

\section{PENDAHULUAN}

\subsection{Latar Belakang}

PT. BNI Syariah Tanjungkarang merupakan lembaga keuangan dengan prinsip syariah yang lahir sebagai salah satu bentuk lembaga keuangan alternatif untuk memenuhi segmentasi masyarakat tertentu yang berpandangan bahwa bunga bank merupakan pelanggaran terhadap Syariat Islam. Produk PT. BNI Syariah Tanjungkarang dapat dibagi menjadi 3 (tiga) bagian yaitu : 1) Produk penyaluran dana, 2) Produk penghimpunan dana, 3) Produk yang berkaitan dengan jasa yang diberikan Perbankan kepada nasabahnya.

Dalam menjalankan kegiatan usahanya berupa produk-produk tersebut, PT. BNI Syariah Tanjungkarang menjalankan sesuai dengan Prinsip-prinsip Syariah yakkni; Prinsip Titipan atau Simpanan (Depository/Al-wadi'ah);
Bagi hasil (Profit Sharing); jual beli (Sale and Purchase); Sewa (Operational Lease and Financial Lease); jasa (Fee Based Services) Dalam mengantisipasi ketatnya persaingan, PT. BNI Syariah Tanjungkarang menerapkan berbagai kebijakan pemasaran yang ditujukan untuk dapat memberikan kepuasan yang diinginkan pelanggan secara lebih baik dibandingkan pesaing. Meskipun saat ini semakin banyaknya perusahaan sejenis yang bergerak dalam bidang pembiayaan konsumen sehingga menyebabkan berfluktuasinya jumlah nasabah selama tahun 2016-2018. Kemudian tingkat persaingan yang terjadi kurang bisa dipahami manajemen sebagai ancaman sehingga ketika ada permasalahan di level bawah tidak bisa diselesaikan secara cepat dan tepat. Karena itu perlu mengadakan pengembangan, inovasi dan 
perubahan dalam strategi pemasaran yang diterapkan selama ini. Permasalahan lain dimana PT. BNI Syariah Tanjungkarang dalam menerapkan kualitas pelayanan tidak memperhatikan faktor-faktor yang mempengaruhi kepuasan nasabah, seperti ketanggapan, keandalan, empati, jaminan dan bukti langsung. Sehingga nasabah belum merasakan adanya kepuasan dari pelayanan yang diberikan selama ini.

Dalam mengantisipasi ketatnya persaingan, pt. bni syariah tanjungkarang menerapkan berbagai kebijakan pemasaran yang ditujukan untuk dapat memberikan kepuasan yang diinginkan pelanggan secara lebih baik dibandingkan pesaing. kebijakan pemasaran tersebut meliputi beberapa kebijakan yaitu:

1. Kebijakan produk; produk adalah suatu sifat yang kompleks baik dapat diraba maupun tidak dapat diraba, termasuk bungkus, warna, harga, prestise perusahaan dan pengecer, pelayanan perusahaan dan pengecer, yang diterima oleh pembeli untuk memuaskan keinginan dan kebutuhannya".

2. Kebijakan harga; dalam penelitian ini, penulis memfokuskan pada pembiayaan bni fleksi syariah. bni fleksi syariah adalah pembiayaan konsumtif bagi pegawai/ karyawan suatu perusahaan/lembaga/instansi untuk pembelian barang dan penggunaan jasa yang tidak bertentangan dengan undangundang/hukum yang berlaku serta tidak termasuk kategori yang diharamkan syariah islam.

3. kebijakan promosi; pt. bni syariah tanjungkarang dalam melakukan kegiatan promosinya dilakukan dengan menggunakan media elektronik, brosurbrosur dan sebagainya. guna memberikan pelayanan yang prima kepada pelanggan, pt. bni syariah tanjungkarang senantiasa mengupayakan dan memperhatikan hal-hal yang diinginkan pelanggan seperti

4. Kebijakan distribusi; saluran distribusi adalah saluran yang digunakan oleh produsen untuk menyalurkan barang tersebut dari produsen sampai ke konsumen atau pemakai industri. kebijakan distribusi yang dilakukan pt. bni syariah tanjungkarang dalam memasarkan pembiayaan bni fleksi syariah adalah dengan saluran distribusi langsung, dimana pt. bni syariah tanjungkarang dalam penyampaiannya langsung kepada para pelanggan.

Hasil ini menunjukkan bahwa kebijakan-kebijakan pemasaran yang dilaksanakan perusahaan belum sepenuhnya memberikan hasil seperti yang diharapkan, khususnya dalam membina hubungan baik dengan pelanggan atau konsumen. untuk itu, perusahaan perlu segera mengetahui dan memahami berbagai hal yang menyangkut dengan perilaku konsumennya.

\subsection{Perumusan masalah}

"Bagaimanakah tingkat kepuasan nasabah pembiayaan BNI Fleksi Syariah pada PT. BNI Syariah Tanjungkarang?"

\subsection{Tujuan Penelitian}

Tujuan yang hendak dicapai dalam penelitian ini yaitu untuk mengetahui tingkat kepuasan nasabah pembiayaan BNI Fleksi Syariah pada PT. BNI Syariah Tanjungkarang.

\section{TINJAUAN PUSTAKA}

\subsection{Pembiayaan BNI Fleksi Syariah}

Pembiayaan BNI Fleksi Syariah adalah pembiayaan konsumtif bagi pegawai/ karyawan suatu Perusahaan/Lembaga/Instansi untuk pembelian barang dan penggunaan jasa yang tidak bertentangan dengan UndangUndang/Hukum yang berlaku serta tidak termasuk kategori yang diharamkan Syariah Islam. Maksimum pembiayaan adalah sebesar Rp.30.000.000,- dan jangka waktu maksimal 3 tahun, kecuali Pegawai BNI dan nasabah kerjasama yaitu sebesar Rp.50.000.000,- dan jangka waktu maksimal 5 tahun dengan batasan jumlah angsuran setiap bulan maksimum $40 \%$ dari total penghasilan setiap bulannya. 


\subsection{Pengertian Pelayanan}

Menurut Philip Kotler (2000: 129), pengertian pelayanan adalah sebagai berikut :

"Pelayanan adalah setiap kegiatan atau manfaat yang ditawarkan oleh suatu pihak kepada pihak lain dan pada dasarnya tidak berwujud, serta tidak menghasilkan kepemilikan sesuatu dalam memasarkan produknya, perusahaan biasanya menyajikan beberapa jasa pelayanan."

Masih menurut Philip Kotler (2000: 437), bahwa pelayanan yang menyertai produk (Product service), dibagi menjadi dua yaitu :

1. Pelayanan sebelum penjualan (Persale Product), termasuk didalamnya periklanan, pameran, nasehat dan sebagainya.

2. Pelayanan sesudah penjualan (post sale service), termasuk di dalamnya mutu pelayanan seperti pelayanan fasilitas dan harga barang.

Sedangkan menurut Kamus Besar Bahasa Indonesia ( 2001: 605), bahwa pelayanan berasal dari kata dasar "layan" atau "melayani", dengan arti sebagai berikut:

1. Membantu Menyiapkan apa-apa yang diperlukan seseorang.

2. Menerima ajakan untuk melaksanakan suatu pekerjaan.

3. Mengendalikan, melaksanakan penggunaannya apa yang diperlukan dalam hal itu.

Sedangkan berdasarkan kata bakunya "Pelayanan" dalam Kamus Besar Bahasa Indonesia (2001: 606) berarti:

1. Perihal atau cara melayani

2. Usaha melayani kebutuhan orang lain dengan memperoleh imbalan (uang).

3. Kemudahan yang diberikan sehubungan dengan jual beli barang atau jasa yang dibutuhkan dalam pelaksanaan untuk melayani.

Menurut Lovelock dan Wright (2005:

98 ) ada 7 (tujuh) kesenjangan kualitas yang menyebabkan ketidakpuasan pelanggan, yang masing-masing dari ketujuh kesenjangan kualitas tersebut dapat merusak hubungan pelanggan. Model ini tampak dalam gambar 1, mengidentifikasi 7 (tujuh) kesenjangan yang memungkinkan dalam kualitas jasa adalah :
1. Kesenjangan pengetahuan; Perbedaan apa yang diyakini penyedia jasa akan diharapkan pelanggan dan kebutuhan dan harapan pelanggan yang sesungguhnya.

2. Kesenjangan standar; Perbedaan antara persepsi manajemen terhadap harapan pelanggan dan standar kualitas yang ditetapkan untuk penyerahan jasa.

3. Kesenjangan penyerahan; Perbedaan antara standar penyerahan yang ditentukan dan kinerja penyedia jasa yang sesungguhnya.

4. Kesenjangan komunikasi internal; Perbedaan antara apa yang dianggap oleh iklan dan tenaga penjual perusahaan tersebut sebagai fitur produk, kinerja, dan tingkat kualitas jasa dan apa yang benarbenar dapat diserahkan oleh perusahaan.

5. Kesenjangan persepsi; Perbedaan antara apa yang benar-benar diserahkan dan apa yang dianggap pelanggan telah mereka terima (karena mereka tidak dapat menilai kualitas jasa secara akurat).

6. Kesenjangan interpretasi; Perbedaan antara apa yang sesungguhnya dijanjikan penyedia jasa dalam upaya-upaya komunikasinya dan apa yang pelanggan pikir telah dijanjikan dalam komunikasi tersebut; Kesenjangan jasa

\subsection{Kepuasan Pelanggan}

Kepuasan adalah tingkat perasaan seseorang setelah membandingkan kinerja (hasil) yang dirasakan dibandingkan dengan harapannya (Philip Kotler, 2000: 46). Menurut J. Supranto (2000: 241), bahwa kriteria untuk mengetahui tingkat kepuasan konsumen biasanya digunakan atau diukur dengan metode analisis tingkat kepentingan dan kinerja/kepuasan pelanggan (Importance Performance Analysis Method) digunakan untuk melihat sampai sejauh mana tingkat kepuasan konsumen terhadap kinerja perusahaan. Berdasarkan hasil penelitian tingkat kepentingan dan hasil penelitian kinerja maka akan dihasilkan suatu perhitungan mengenai tingkat kesesuaian antara tingkat kepentingan dengan tingkat pelaksanaannya oleh perusahaan. Tingkat kesesuaian adalah hasil perbandingan skor kinerja/pelaksanaan 
dengan skor kepentingan. Tingkat kesesuaian

inilah yang akan menentukan prioritas peningkatan faktor-faktor yang mempengaruhi kepuasan konsumen.

\section{Gambar 1.}

Konsep Tujuh Kesenjangan Kualitas yang Menyebabkan

Ketidakpuasan

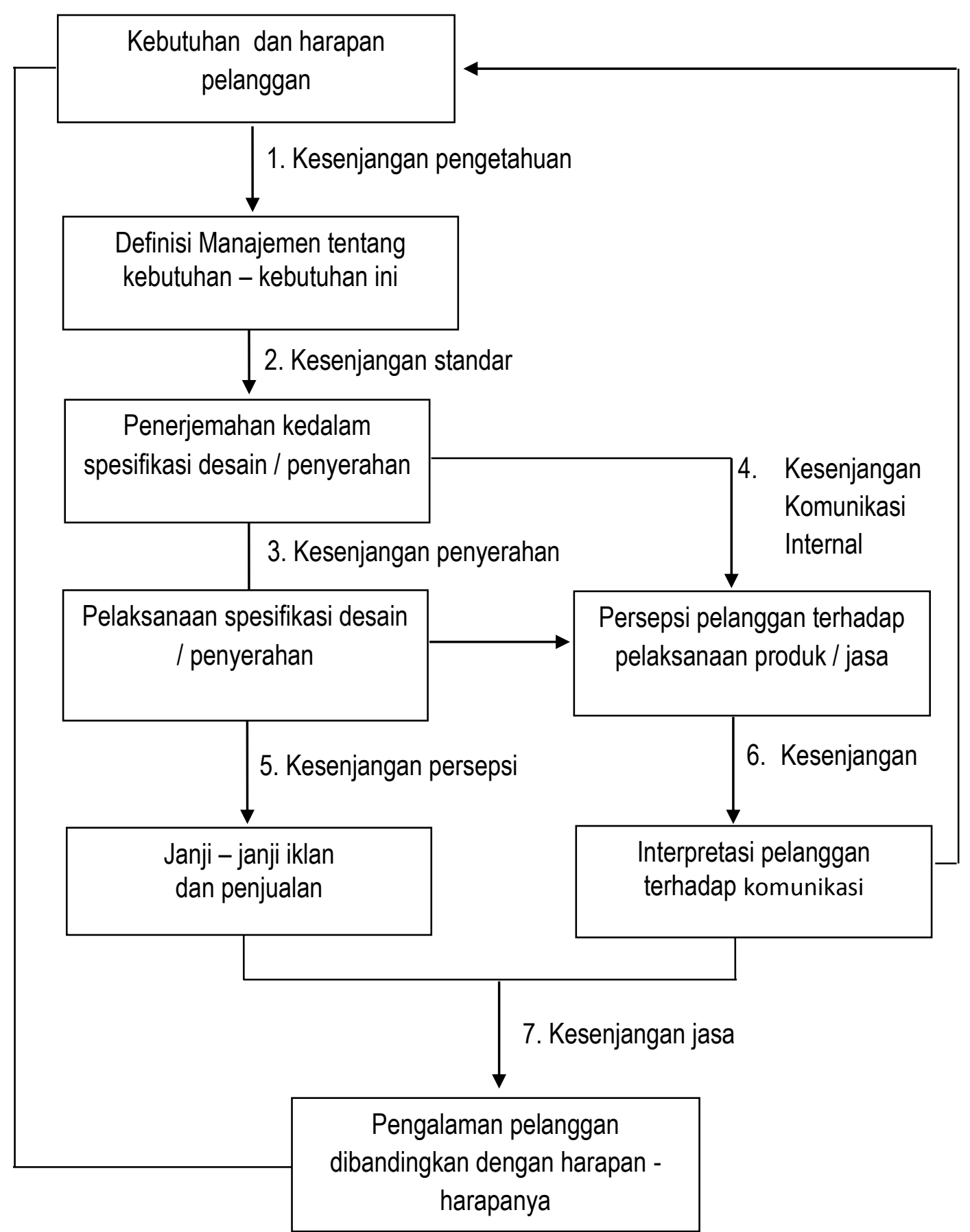

Sumber: Disadur dari Christopher Lovelock, product plus (New York : McGraw - Hill, 1994), 112

\subsection{Hipotesis}

Pelayanan yang diberikan oleh PT. BNI

Syariah Tanjungkarang kepada nasabah
Pembiayaan BNI Fleksi Syariah belum sesuai dengan keinginan nasabah. 


\section{METODE PENELITIAN}

\subsection{Jenis Penelitian}

Jenis penelitian deskriptif, sumber data yang digunakan dalam penelitian ini adalah Data Primer yang diperoleh dengan cara mengadakan penelitian lapangan pada PT. BNI Syariah Tanjungkarang. Selain iru menggunakan Data Sekunder yang diterima dengan mempelajari buku-buku dan ketentuan lain yang disesuaikan dengan penelitian.

\subsection{Populasi dan Sampel}

\section{Populasi}

Populasi dalam penelitian ini adalah karyawan BUMN yaitu sebanyak 8 (delapan) instansi sebagai nasabah Pembiayaan BNI Fleksi Syariah pada PT. BNI Syariah Tanjungkarang dari bulan Oktober 2006 - Juni 2018 yang berjumlah 129 orang, sedangkan untuk nasabah Pembiayaan BNI Fleksi Syariah secara keseluruhan berjumlah 129 orang. Sampel adalah bagian dari jumlah dan karakteristik yang dimiliki oleh populasi. Dalam penelitian ini, sampel yang diambil yaitu seluruh jumlah populasi sebanyak 129 orang, sehingga penelitian ini merupakan penelitian populasi. Karakteristik populasi dalam penelitian ini yaitu Nasabah Pembiayaan BNI Fleksi Syariah dengan kriteria : 1) Status pegawai aktif pada BUMN; 2) Minimal berusia 21 tahun; 3) Mempunyai masa kerja minimal 3 tahun sebagai pegawai tetap; 4) Mempunyai sumber pembayaran tetap serta mampu mengangsur.

Tabel 1.

Jumlah Populasi dalam Penelitian

\begin{tabular}{clc}
\hline No & \multicolumn{1}{c}{ Nama Instansi } & Jumlah \\
\hline 1. & PT. Bank BNI & 50 \\
\hline 2. & PT. Bank BNI Syariah & 16 \\
\hline 3. & PT. Bank BRI & 4 \\
\hline 4. & PT. Bank BRI Syariah & 7 \\
\hline 5. & PT. Kereta Api Indonesia & 23 \\
\hline 6. & PT. Perusahaan Listrik Negara & 14 \\
\hline 7. & PT. Pelabuhan Indonesia II & 4 \\
\hline \multirow{2}{*}{ 8. PT. Rajawali Nusantara } & 11 \\
\hline \multicolumn{3}{c}{ Pndonesia } \\
\hline \multicolumn{2}{c}{ Total } & 129 \\
\hline
\end{tabular}

\subsection{Teknik Pengumpulan Data}

Pengumpulan data merupakan suatu proses pengadaan data primer untuk keperluan penelitian, secara umum metode pengumpulan data pada penelitian ini meliputi wawancara; yaitu Pengambilan data tersebut dengan melakukan wawancara kepada Manajemen PT. BNI Syariah Tanjungkarang, seperti tentang kondisi lingkungan kantor, pelayanan dan lainlain.

Observasi yaitu pengumpulan data dan informasi dengan menggunakan pengamatan langsung terhadap pelaksanaan obyek penelitian yang ada hubungannya dengan data dan informasi yang diperlukan, guna memperoleh gambaran yang jelas mengenai perusahaan serta mencocokkan keterangan yang didapat melalui wawancara.

\subsection{Teknik Analisis Data}

Analisis kualitatif, yaitu menganalisis masalah dan permasalahan yang ada berdasarkan konsep manajemen pemasaran, khususnya teori-teori mengenai pelayanan yang tujuannya untuk meningkatkan kepuasan konsumen, dalam hal ini digunakan alat analisis tabel. Analisis kuantitatif, yaitu menganalisa data dengan menggunakan rumus yaitu Diagram Kartesius (Performance Analysis).

1. Menghitung tingkat kesesuaian responden

$$
\begin{array}{ll}
\text { Tki }= & \frac{\mathrm{Xi}}{\mathrm{Yi}} \times 100 \% \\
\text { Di mana: } & \\
\mathrm{Tki}= & \text { Tingkat kesesuaian responden } \\
\mathrm{Xi}= & \text { Skor penilaian pelayanan } \\
\mathrm{Yi}= & \text { Skor penilaian kepuasan } \\
\text { pelanggan } &
\end{array}
$$

2. Menghitung skor rata-rata

$$
\bar{X}=\frac{\sum X i}{n} \text { dan } \bar{Y}=\frac{\sum Y i}{n}
$$

Di mana :

$\bar{X}=$ Skor rata-rata tingkat pelayanan

$\overline{\mathrm{Y}}=$ Skor rata-rata tingkat kepuasan pelanggan

$\mathrm{n}=$ Jumlah responden 
3. Menghitung rata-rata dari skor

$$
\begin{array}{ll}
X= & \frac{\sum_{i=1}^{n} X i}{K} \\
Y= & \frac{\sum_{i=1}^{n} Y i}{K} \\
\text { Di mana: } & \\
K= & \text { Banyaknya atribut }
\end{array}
$$

$X=\quad$ Rata-rata dari rata-rata skor tingkat pelayanan

$Y=\quad$ Rata-rata dari rata-rata skor tingkat kepuasan pelanggan

Diagram kartesius dari PerformanceImportance dapat dilihat pada gambar di bawah ini.

Diagram kartesius dari PerformanceImportance dapat dilihat pada gambar di bawah ini.

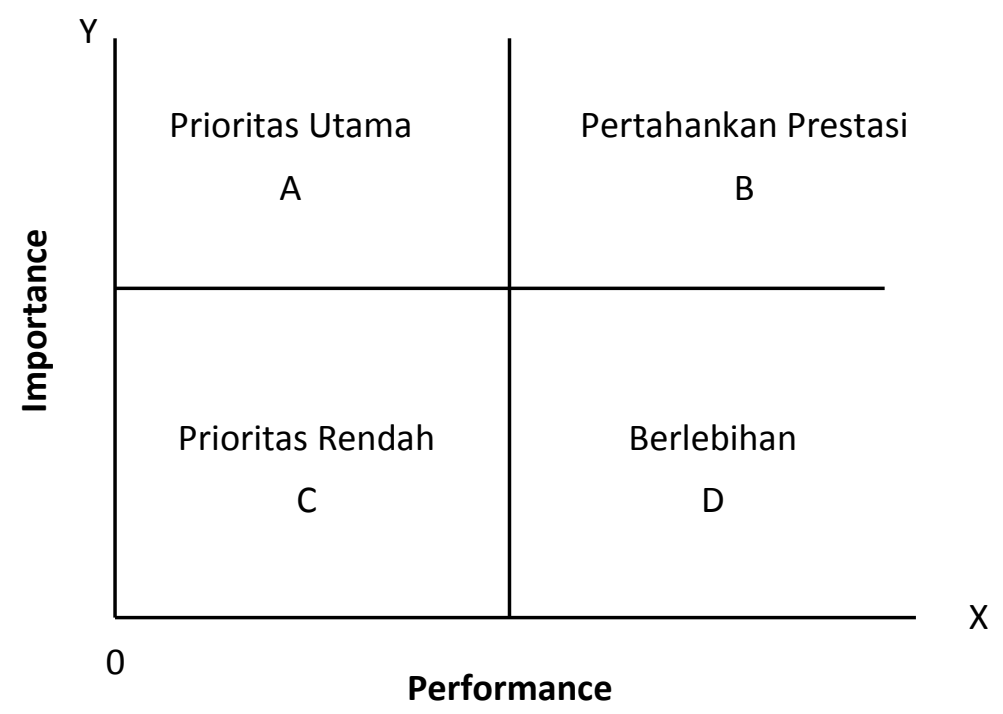

1. Kuadra A: Menunjukkan faktor atau atribut yang dianggap mempengaruhi kepuasan pelanggan, termasuk unsur-unsur jasa yang dianggap sangat penting, namun manajemen belum melaksanakannya sesuai keinginan pelanggan. Sehingga mengecewakan/tidak puas.

2. Kuadran B: Menunjukkan unsur jasa pokok yang telah berhasil dilaksanakan perusahaan, untuk itu wajib dipertahankannya. Dianggap sangat penting dan sangat memuaskan.

3. Kuadran C: Menunjukkan beberapa faktor yang kurang penting pengaruhnya bagi pelanggan, pelaksananya oleh perusahaan biasa-biasa saja. Dianggap kurang penting dan kurang memuaskan.

4. Kudran D: Menunjukkan faktor yang mempengaruhi pelanggan kurang penting, akan tetapi pelaksanaanya berlebihan. Dianggap kurang penting tetapi sangat memuaskan.
IV. HASIL PENELITIAN DAN PEMBAHASAN

4.1 Penilaian Tingkat (Performance)1

1. Keandalan (Reliability); Kemudahan dalam mengakses teknologi; Kemudahan dalam pelayanan.

2. Keresponsifan (Responsiveness); Ketanggapan menangani keluhan nasabah; Tindak lanjut petugas bila ada masalah.

3. Keyakinan (Assurance); Pengetahuan, kemampuan dan kecakapan; Tingkat dedikasi, kejujuran dan loyalitas.

4. Empati (Emphaty); Kemampuan memahami keinginan nasabah; Etika, sopan santun dan bahasa petugas.

5. Bukti Langsung (Tangible); Kemudahan dalam sistem administrasi dan pembayaran; Kelengkapan fasilitas administrasi dan teknisi 
Berdasarkan tanggapan responden mengenai bukti langsung (tangible) di atas, menunjukkan bahwa fasilitas yang disediakan oleh perusahaan sudah memenuhi keinginan nasabah untuk memperoleh jasa yang disediakan perusahaan.

Tanggapan di atas pada dasarnya turut mendorong timbulnya motivasi konsumen dalam menggunakan jasa pembiayaan, di mana kondisi fasilitas yang baik akan mendorong timbulnya motivasi tersebut. Secara keseluruhan kondisi dan fasilitas yang disediakan akan mampu mempengaruhi sikap dan emosi konsumen selama proses transaksi berjalan.

\subsection{Penilaian Tingkat Kepentingan (Importance)}

Untuk mengetahui penilaian responden terhadap tingkat kepentingan terhadap pelayanan yang diberikan disajikan sebagai berikut :

1. Keandalan (Reliability); Kemudahan dalam mengakses teknologi; Kemudahan dalam pelayanan

2. Keresponsifan (Responsiveness); Ketanggapan menangani keluhan nasabah; Tindak lanjut petugas bila ada masalah
3. Keyakinan (Assurance); Pengetahuan, kemampuan dan kecakapan; Tingkat dedikasi, kejujuran dan loyalitas

4. Empati (Emphaty); Kemampuan memahami keinginan nasabah; Etika, sopan santun dan bahasa petugas

5. Bukti Langsung (Tangible); Kemudahan dalam sistem administrasi dan pembayaran; Kelengkapan fasilitas administrasi dan teknisi

Tanggapan di atas pada dasarnya turut mendorong timbulnya motivasi konsumen dalam menggunakan jasa pembiayaan di mana kondisi dan fasilitas yang baik akan mendorong timbulnya motivasi tersebut. Secara keseluruhan kondisi dan fasilitas yang disediakan akan mampu mempengaruhi sikap dan emosi konsumen selama proses transaksi berjalan.

\subsection{Interpretasi}

Berdasarkan hasil penyajian dari Tabel 5 sampai dengan Tabel 24, maka diperoleh hasil skor rata-rata jawaban responden dari tingkat kinerja (performance) dan tingkat kepentingan (importance), yaitu dengan cara mengurangkan rata-rata Importance dengan rata-rata Performance, sehingga diperoleh kriteria sebagai berikut :

Tabel 2.

Rekapitulasi Skor Rata-rata Jawaban Responden

\begin{tabular}{|c|c|c|c|c|}
\hline No & Item Pertanyaan & Importance & performance & Kuadran \\
\hline \multirow[t]{3}{*}{1.} & Reliability (Keandalan) & & & \\
\hline & 1. Kemudahan dalam mengakses teknologi & 4,22 & 4,03 & B \\
\hline & 2. Kemudahan dalam pelayanan & 4,12 & 3,95 & A \\
\hline \multirow[t]{3}{*}{2.} & Responsiveness (Keresponsifan) & & & \\
\hline & 1. Ketanggapan menangani keluhan nasabah & 4,11 & 3,87 & A \\
\hline & 2. Tindak lanjut petugas bila ada masalah & 4,00 & 3,88 & C \\
\hline \multirow[t]{3}{*}{3.} & Assurance (Keyakinan) & & & \\
\hline & 1. Pengetahuan, kemampuan dan kecakapan & 4,12 & 4,08 & B \\
\hline & Tingkat dedikasi, kejujuran dan loyalitas & 4,26 & 4,29 & B \\
\hline \multirow[t]{3}{*}{4.} & Emphaty (Empati) & & & \\
\hline & 1. Kemampuan memahami keinginan nasabah & 4,08 & 3,89 & A \\
\hline & Etika, sopan santun dan bahasa petugas & 3,88 & 3,94 & C \\
\hline \multirow[t]{3}{*}{5.} & Tangible (Bukti langsung) & & & \\
\hline & $\begin{array}{l}\text { 1. Kemudahan dalam sistem administrasi dan } \\
\text { pembayaran }\end{array}$ & 3,74 & 3,76 & C \\
\hline & Kelengkapan fasilitas administrasi dan teknisi & 3,88 & 3,92 & C \\
\hline
\end{tabular}

Sumber : Data Diolah, 2018 
Keterangan :

$$
\begin{array}{rlr}
\mathrm{I} & = & \text { Importance } \\
\overline{\mathrm{Y}} & =\frac{\sum_{\mathrm{i}=1}^{\mathrm{n}} \mathrm{Yi}}{\mathrm{K}} \\
& =\frac{40,40}{10} \\
& =\frac{4,04}{\mathrm{~N}} \\
\overline{\mathrm{X}} & \frac{\sum_{\mathrm{i}=1}^{\mathrm{X}} \mathrm{Xi}}{\mathrm{K}} \\
& =\frac{39,61}{10} \\
& =3,96
\end{array}
$$

Kuadran $A=(\bar{Y}>4,04 ; \bar{X}<3,96)$

Kuadran $B=(\bar{Y}>4,04 ; \bar{X}>3,96)$

Kuadran $\mathrm{C}=(\overline{\mathrm{Y}}<4,04 ; \overline{\mathrm{X}}<3,96)$

Kuadran $\mathrm{D}=(\overline{\mathrm{Y}}<4,04 ; \overline{\mathrm{X}}>3,96)$
Berdasarkan hasil perhitungan Importence - Performance Analysis diketahui bahwa rata-rata tingkat harapan nasabah keseluruhan adalah 4,04 dan rata-rata tingkat pelayanan yang diberikan PT. BNI Syariah secara keseluruhan adalah 3,96 . Hal ini menunjukkan 4,04 > 3,96, yang berarti tingkat harapan nasabah lebih besar dibandingkan pelayanan yang diberikan PT. BNI Syariah atau pelayanan yang diberikan masih belum sesuai dengan harapan nasabah. Setelah diketahui hasil tersebut maka dapat dilakukan analisis atribut-atribut atau faktor-faktor kepuasan nasabah terhadap pelayanan pada PT. BNI Syariah dalam diagram kertesius yang terbagi dalam empat ruang. Dapat dilihat pada gambar di bawah ini.

Gambar 2.

Diagram Kartesius Performance dan Importance

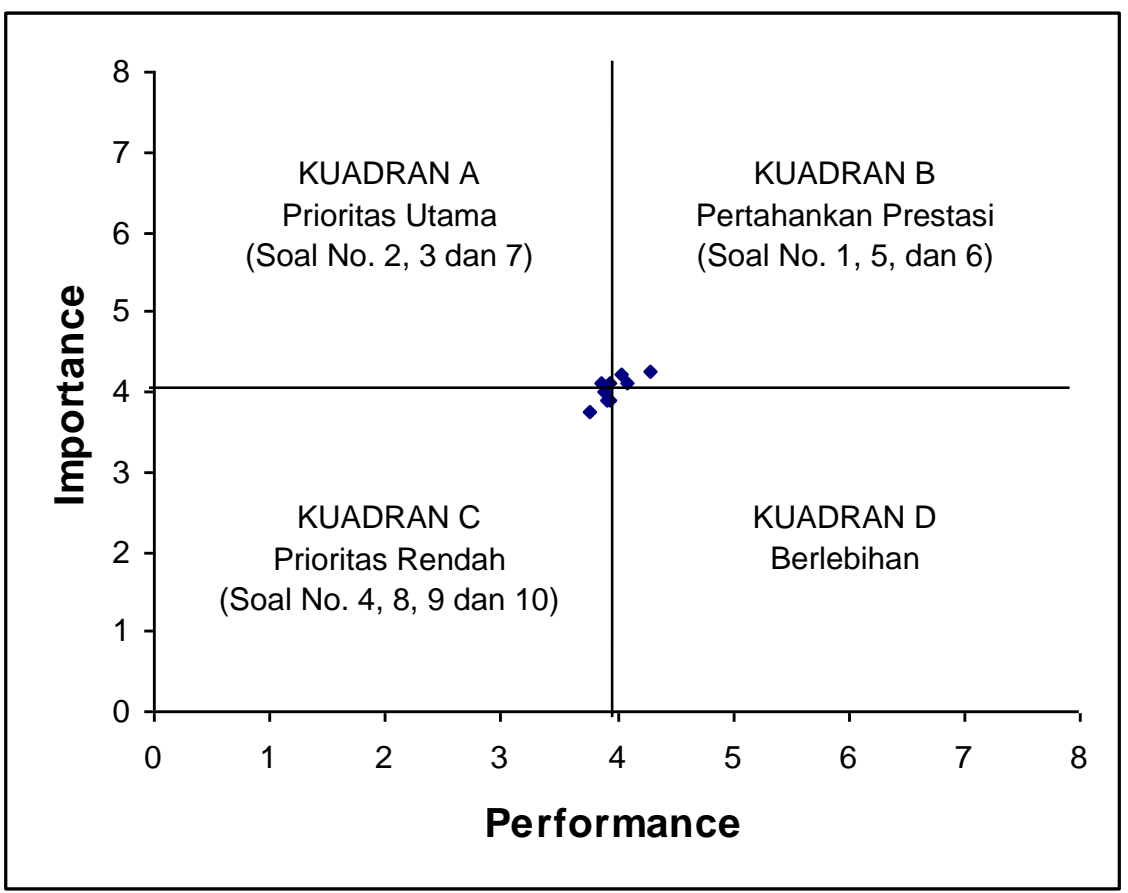

Penjelasan kuadran dalam gambar di atas, yaitu :
1. Kuadran $A$; Menunjukkan atribut yang mempengaruhi kepuasan nasabah PT. BNI Syariah yang penanganannya perlu 
diprioritaskan oleh perusahaan karena keberadaan faktor inilah yang dinilai sangat penting oleh nasabah, namun manajemen belum melaksanakannya sesuai keinginan pelanggan. Atribut yang termasuk dalam kuadran A adalah; Kemudahan dalam pelayanan; Ketanggapan menangani keluhan nasabah.; Kemampuan memahami keinginan nasabah.

2. Kuadran B; Menunjukkan atribut-atribut yang mempengaruhi kepuasan nasabah PT. BNI Syariah yang perlu dipertahankan, karena pada umumnya tingkat pelaksanaannya telah sesuai dengan kepentingan dan harapan nasabah, sehingga dapat memuaskan nasabah. Atribut yang termasuk dalam kuadran B adalah Kemudahan dalam mengakses teknologi; Pengetahuan, kemampuan dan kecakapan; Tingkat dedikasi, kejujuran dan loyalitas.

3. Kuadran C; Menunjukkan atribut yang mempengaruhi kepuasan nasabah PT. BNI Syariah yang dinilai masih dianggap kurang penting pengaruhnya bagi pelanggan, pelaksanaannya oleh perusahaan biasa-biasa saja. Dianggap kurang penting dan kurang memuaskan. Atribut yang termasuk dalam kuadaran $\mathrm{C}$ adalah Tindak lanjut petugas bila ada masalah; Etika, sopan santun dan bahasa petugas; Kemudahan dalam sistem administrasi dan pembayaran. Kelengkapan fasilitas administrasi dan teknisi.

4. Kuadran D; Menunjukkan atribut yang mempengaruhi kepuasan nasabah PT. BNI Syariah yang dinilai berlebihan pelaksanaannya, hal ini terutama disebabkan karena nasabah menganggap tidak terlalu penting terhadap adanya atribut tersebut, akan tetapi pelaksanaannya dilakukan dengan baik sekali oleh perusahaan sehingga sangat memuaskan dan tidak ada atribut yang termasuk dalam kuadaran D.

Dalam rangka menyikapi ketidakpuasan nasabah pada PT. BNI Syariah
Tanjungkarang, maka upaya yang perlu dilakukan yaitu :

1. Perusahaan harus menerapkan standarisasi dalam pelayanan yang mengacu pada standar pelayanan internasional di bidang perbankan.

2. Memberikan kesempatan kepada seluruh karyawan untuk meningkatkan kemampuan dan keterampilannya dengan cara mengikuti seminar-seminar, lokakarya serta pelatihan-pelatihan yang diadakan baik yang diadakan oleh pihak internal maupun eksternal dalam kaitannya dengan pelayanan Perbankan Nasional.

Berdasarkan hasil analisis tersebut di atas, maka hipotesis yang penulis ajukan bahwa Pelayanan yang diberikan oleh PT. BNI Syariah Tanjungkarang kepada nasabah Pembiayaan BNI Fleksi Syariah belum sesuai dengan keinginan nasabah, terbukti dan dapat diterima.

\section{SIMPULAN DAN SARAN}

\subsection{Simpulan}

1. Faktor-faktor yang yang mempengaruhi kepuasan nasabah PT. BNI Syariah yang penanganannya perlu diprioritaskan oleh perusahaan karena keberadaan faktor inilah yang dinilai sangat penting oleh nasabah, namun manajemen belum melaksanakannya sesuai keinginan pelanggan.

2. Faktor-faktor atau variabel yang mempengaruhi kepuasan nasabah PT. BNI Syariah yang perlu dipertahankan, karena pada umumnya tingkat pelaksanaannya telah sesuai dengan kepentingan dan harapan nasabah, sehingga dapat memuaskan nasabah.

3. Faktor-faktor atau variabel yang mempengaruhi kepuasan nasabah PT. BNI Syariah yang dinilai masih dianggap kurang penting pengaruhnya bagi pelanggan, pelaksananya oleh perusahaan biasa-biasa saja.

4. Tingkat kinerja paling tinggi adalah tingkat dedikasi, kejujuran dan loyalitas dengan rata-rata skor sebesar 4,29. Hal ini menunjukkan bahwa tingkat dedikasi, 
kejujuran dan loyalitas yang dimiliki oleh karyawan sudah sesuai dengan keinginan dan harapan nasabah. Sedangkan tingkat kinerja paling rendah adalah kemudahan dalam sistem administrasi dan pembayaran dengan rata-rata skor sebesar 3,76. Hal tersebut disebabkan kecenderungan responden untuk melakukan transaksi secara manual pada PT. BNI Syariah Tanjungkarang, padahal transaksi tersebut bisa dilaksanakan secara on line pada Bank BNI terdekat.

5. Tingkat kepentingan yang paling tinggi adalah tingkat dedikasi, kejujuran dan loyalitas dengan rata-rata skor sebesar 4,26. Hal ini disebabkan nasabah menginginkan adanya sikap jujur dari setiap karyawan dalam setiap transaksi yang terjadi serta mengharapkan adanya karyawan yang benar-benar memiliki dedikasi yang tinggi. Sedangkan tingkat kepentingan yang paling rendah adalah kemudahan dalam sistem administrasi dan pembayaran dengan skor rata-rata sebesar 3,74. Hal ini disebabkan sistem pembayaran yang diterapkan oleh PT. BNI Syariah Tanjungkarang sudah dapat dilaksanakan baik secara manual, secara on line dari Bank BNI terdekat maupun melalui ATM BNI.

\subsection{Saran}

1. Pihak manajemen PT. Bank BNI Syariah Tanjungkarang hendaknya mengadakan pendidikan dan pelatihan kepada seluruh karyawannya terutama untuk meningkatkan kemampuan karyawan dalam hal; Ketanggapan menangani keluhan pelanggan; Kemampuan memahami keinginan pelanggan.

2. Hendaknya manajemen PT. Bank BNI Syariah Tanjungkarang tetap mempertahankan; Tingkat dedikasi, kejujuran dan loyalitas; Etika, sopan santun dan bahasa petugas.

\section{DAFTAR PUSTAKA}

Ariani, D. Wahyu, 2003, Manajemen Kualitas Pendekatan Sisi Kualitatif, Penerbit PT Ghalia Indonesia, Jakarta.

Day, Ralp L. and E. Laird Landon, Jr. "Toward a Theory of Consumer Complaning Behavior", dalam Consumer and Industrial Buying Behavior, Editor Arch G. Woodside, Jagdish N. Smeth an. Peter D. Bennet, 1997, Elsevier North Holland, New York.

Kotler, P., 1997, Manajemen Pemasaran, Analisis, Perencanaan, Implementasi, dan Kontrol, Jilid I dan II, Edisi Kesembilan, Alih Bahasa oleh Hendra Teguh dan Romli A., Penerbit PT. Prenhallindo, Jakarta.

Lovelock, Christopher H. dan Lauren K Wright, 2005, Manajemen Pemasaran Jasa, Penerbit Indeks, Jakarta.

Rangkuti, F., 2002, Measuring Customer Service, PT. Gramedia Pustaka Utama, Jakarta.

Setiadi, Nugroho J., 2003, Perilaku Konsumen : Konsep dan Implikasi untuk Strategi dan Penelitian Pemasaran, PT Kencana, Jakarta.

Sugyiono, 2003, Metode Penelitian Bisnis, Penerbit CV. Alfabeta, Bandung.

Sumbogo, B., 2000, Analisis Kepuasan Konsumen dalam Rangka Strategi Pemasaran pada PT. Telkom Area Lampung, Tesis Magister Manajemen Program Pascasarjana, Universitas Bandar Lampung.

Supranto, J., 1997, Metode Riset, Aplikasi dalam Pemasaran, Penerbit Fakultas Ekonomi Universitas Indonesia, Jakarta.

Swastha D.H, B. dan Irawan, 2000, Manajemen Pemasaran Modern, Penerbit Liberty, Yogyakarta.

Swastha D.H., B. dan Ibnu Sukotjo W., 2002, Pengantar Bisnis Modern (Pengantar Ekonomi Perusahaan Modern), Edisi Ketiga, Penerbit Liberty, Yogyakarta. 